Kapata Arkeologi, 13(1), 83-94

ISSN (cetak): 1858-4101

ISSN (elektronik): 2503-0876

http://kapata-arkeologi.kemdikbud.go.id

\title{
SITUS-SITUS MEGALITIK DI KABUPATEN WAJO, SULAWESI SELATAN
}

\author{
Megalithic Sites in Wajo, South Sulawesi
}

\author{
Hasanuddin \\ Balai Arkeologi Sulawesi Selatan - Indonesia \\ Jl. Pajjaiyyang No. 13 Sudiang, Makassar \\ udin.balar@gmail.com
}

Naskah diterima: 04/03/2017; direvisi: 22/03 - 16/06/2017; disetujui: 19/06/2017

Publikasi ejurnal: 25/07/2017

\begin{abstract}
Wajo in South Sulawesi is a region that has been known have findings from Islamic period, so it tends to be categorized as an area that civilization started around the $17^{\text {th }}$ century AD. Research in Wajo intended to get an overview of distribution and development of the megalithic period, which is also known as the beginning of civilization. In its achieving, the survey method is used to determine the distribution of megalithic synchronization and also excavations conducted at the Cilellang site to reveal the variability of finds in the cultural layers and development of the megalithics in diachronic. Obtained a description of the research, Cilellang, Tobattang and Allangkanange megalithic sites developed since $13^{\text {th }}$ until $15^{\text {th }}$ century $A D$ in the southeast of Tempe Lake. Agricultural activity is the main livelihood that is marked by 36 mortar stone finds on all three sites. Those three sites can also give an overview of the hierarchy of Allangkanange settlements that may have high social strata because it has the most extensive sites, more varied archaeological remains, and a higher location. Probably Allangkanange is the administrative center of Tobattang and Cilellang sites.
\end{abstract}

Keywords: megalithic site hierarchy, settlements

\begin{abstract}
Abstrak
Kabupaten Wajo di Sulawesi Selatan merupakan daerah yang selama ini diketahui memiliki temuan-temuan masa Islam, sehingga cenderung dikategorikan sebagai daerah yang memulai peradabannya sekitar abad ke-17 Masehi. Penelitian di Wajo dimaksudkan untuk memperoleh gambaran mengenai distribusi dan masa perkembangan megalitik, dan juga dapat menandai awal peradabannya. Dalam pencapaiannya, digunakan metode survei untuk mengetahui distribusi megalitik secara sinkronis dan dilakukan ekskavasi di situs Cilellang untuk mengetahui variabilitas temuan dalam lapisan budaya dan masa perkembangan megalitik secara diakronis. Dari penelitian diperoleh gambaran bahwa situs Cilellang, Tobattang dan Allangkanange merupakan situs megalitik yang berkembang sejak abad ke13 hingga abad ke-15 M di wilayah sebelah tenggara Danau Tempe. Aktivitas pertanian merupakan mata pencaharian pokok ditandai dengan temuan 36 lumpang batu pada ketiga situs tersebut. Ketiga situs juga dapat memberi gambaran secara hirarki, yaitu situs Allangkanange mungkin mempunyai strata sosial permukiman yang lebih tinggi dibandingkan situs Cilellang dan Tobattang, karena memiliki luas situs paling besar, tinggalan arkeologi yang lebih bervariatif dan lokasi yang lebih tinggi. Mungkin saja situs Allangkanange adalah pusat pemerintahan dari situs Cilellang dan Tobattang.
\end{abstract}

Kata kunci: megalitik, hirarki situs, permukiman 


\section{PENDAHULUAN}

Kabupaten Wajo merupakan salah satu kabupaten di Provinsi Sulawesi Selatan dengan ibukota Sengkang. Kabupaten ini terletak sekitar $242 \mathrm{~km}$ dari Kota Makassar dan dapat ditempuh sekitar empat jam dengan menggunakan kendaraan roda dua maupun roda empat. Secara geografis, Kabupaten Wajo terletak pada koordinat antara $30^{\circ} 39^{\prime}$ sampai $4^{\circ}$ $16^{\prime}$ Lintang Selatan dan $119^{\circ} 53^{\prime}$ sampai $120^{\circ}$ 27' Bujur Timur dengan luas wilayah mencapai 2.506,19 km. ${ }^{2}$ Kabupaten Wajo terletak di antara kabupaten lain, yaitu di sebelah utara Kabupaten Luwu dan Kabupaten Sidrap; di sebelah selatan Kabupaten Soppeng dan Bone; di sebelah timur Teluk Bone dan di sebelah barat Kabupaten Soppeng dan Sidrap.

Penelitian untuk tujuan rekonstruksi sejarah kebudayaan Wajo telah banyak dilakukan, baik dari kalangan peneliti, akademisi, maupun dari kalangan mahasiswa arkeologi dan sejarah dalam rangka penulisan skripsi. Para mahasiswa yang telah meneliti dalam rangka penulisan skripsi di antaranya Duli (1988); Hamris (1990); Nurhikmah (1995). Sementara itu dari kalangan peneliti yang telah melakukan penelitian di antaranya Hadimulyono (1985) dan Kallupa (1987). Penelitian arkeologi oleh Bulbeck et al. (2008; 2009), Caldwell (1995), Kaluppa (1987) dan Duli (2010) telah cukup banyak menambah pengetahuan kita tentang masa pra-Islam di Sulawesi Selatan. Kebanyakan dari penelitian ini bersandar pada analisis statistik terhadap fragmen keramik yang dikumpulkan dari permukaan bekas permukiman atau pada situssitus ritual. Hasil analisis tersebut dapat merekonstruksi sejarah kependudukan dari populasi orang-orang yang bermukim pada daerah-daerah yang diteliti, yakni di daerahdaerah bekas kerajaan Bugis dan Makassar, Sulawesi Selatan, selama masa beberapa ratus tahun (Caldwell, 1995; Bulbeck et al., 2000).

Beberapa sejarawan mengungkapkan bahwa Wajo memulai pemerintahannya dan tampil menjadi salah satu kerajaan yang berpengaruh pada abad ke-15 Masehi. Salah satu karya yang bersifat fundamental telah dilakukan oleh Abidin (1985) yang mengulas sejarah Wajo abad ke-15-16 Masehi dengan kajian naskah lontara. Dalam naskah lontara disebutkan bahwa peradaban Wajo dimulai pada abad ke-15 M (Abidin, 1985; Patunru,
1983). Diduga, cikal bakal terbentuknya permukiman Wajo berdasarkan naskah lontara pada awalnya berkedudukan di Cinnatobi.

Secara arkeologis, kronologi munculnya belum diketahui secara pasti, tetapi tampil menjadi salah satu daerah yang berpengaruh. Untuk merekonstruksi sejarah kebudayaan suatu daerah, harus melalui kajian yang mendalam dengan dukungan data yang lebih maksimal. Sumber lontara ini masih harus diuji secara arkeologis melalui survei dan ekskavasi arkeologis. Dalam perspektif arkeologis, untuk merekonstruksi sejarah kebudayaan suatu daerah, harus melalui kajian mendalam dengan berbagai tingkat variabilitas data yang tinggi. Dengan demikian, untuk mengetahui eksistensi peradaban Wajo dan aktivitas yang pernah berlangsung dalam rentang waktu tertentu, perlu dukungan data artefaktual. Diharapkan dari sejumlah variabel temuan data artefaktual dapat memberikan penjelasan empiris dalam menyusun sejarah kebudayaan Wajo.

Salah satu kajian yang cukup menarik dalam perspektif arkeologi adalah penelitian yang dilakukan oleh Bulbeck tahun 1996 berupa ekskavasi di situs Allangkanange. Hasil penelitiannya diterbitkan tahun 2009, menyimpulkan bahwa Allangkanange di Pammana merupakan pusat Kerajaan Wajo kuno sekitar abad ke-13-17 Masehi (Bulbeck et al., 2009).

Dari hasil penjaringan data kepustakaan, tampaknya sangat menarik melakukan eksplorasi sistematis untuk menemukan penjelasan proses budaya pada beberapa toponim tua di Wajo dari masa protosejarah hingga masa pra-Islam. Studi arkeologi yang telah dilakukan sebelumnya oleh beberapa peneliti, berorientasi pada skala situs atau hanya sampai pada tingkat identifikasi, sehingga masih sulit menarik benang merah kerangka sejarah kebudayaan Wajo dari periode awal pemukiman oleh sekelompok kecil masyarakat (bands) sampai berkembangnya masyarakat setingkat kerajaan (state). Penemuan arkeologis menjadi penting untuk meletakkan Wajo dalam kerangka sejarah kebudayaan jazirah selatan Sulawesi dan menggambarkan cara manusia mengadaptasi kondisi setempat.

Penelitian yang dilakukan pada sejumlah situs yang memiliki indikasi kuat untuk menggambarkan awal peradabannya, merupakan bentuk penelitian eksploratif dengan 
teknik survei dan ekskavasi. Sejumlah toponim yang tercantum dalam naskah lontara menyiratkan kisah perjalanan sejarah budaya Wajo dengan sistem pemerintahannya. Namun permasalahannya adalah bahwa situs-situs yang digambarkan dalam naskah lontara telah banyak mengalami perubahan terutama disebabkan oleh semakin padatnya penduduk yang bermukim sekarang ini. Dalam kaitan itu, pada kesempatan ini akan digambarkan dua permasalahan:

Pertama, bagaimana karakteristik budaya pada setiap situs atau toponim tua di Wajo yang menandai awal peradabannya. Kedua, kapan penghunian awal situs-situs megalitik di Wajo.

\section{METODE}

Penelitian difokuskan pada tiga situs yang terletak di sebelah tenggara Danau Tempe. Penelitian menggunakan metode survei dan ekskavasi dengan penjelasan secara deskriptifinterpretatif. Survei difokuskan di situs Cilellang yang luasnya $\pm 1,1 \mathrm{~km}^{2}$. Selain itu, dilakukan ekskavasi di situs ini untuk mengetahui variabilitas temuan pada setiap lapisan budaya dan kronologi situs dalam konteks temuan megalitik. Metode ekskavasi dilakukan di situs Cilellang dengan pertimbangan: (i) memiliki luas yang cukup signifikan untuk menggambarkan bekas permukiman manusia (ii) memiliki temuan permukaan yang bervariasi seperti tembikar, keramik asing, dan lumpang batu. Selanjutnya dilakukan analisis yang mengelompokkan jenis temuan berdasarkan atribut bentuk, teknologi dan menganalisis secara kontekstual untuk memperoleh gambaran mengenai ciri-ciri dari masa yang diwakilinya. Penentuan pertanggalan dilakukan melalui analisis radiokarbon (C14) berdasarkan temuan arang yang diperoleh dari ekskavasi. Sampel arang selanjutnya dikirim ke Pusat Aplikasi Isotop dan Radiasi, Batan di Jakarta untuk ditarikhkan.

Untuk menjaring data dengan areal survei yang lebih luas, maka survei juga dilakukan di situs Tobattang dan Allangkanange. Tujuannya adalah untuk mengetahui variabilitas temuan artefak pada masing-masing situs tersebut sehingga tergambar secara hirarki. Khusus analisis tembikar dilakukan pemetikan sampel secara acak pada dua situs, yaitu Cilellang dan Tobattang, dan tidak dilakukan pemetikan sampel tembikar dari situs Allangkanange karena sebagian besar fragmen tepian tembikar yang ditemukan di situs Allangkanange telah hancur dan ukuran diemeter tepian yang dominan kurang dari 20 persen. Hal tersebut disebabkan oleh aktivitas berkebun yang rutin dilakukan di permukaan situs. Pemetikan sampling dilakukan untuk tujuan identifikasi beberapa bentuk motif hias tembikar. Jumlah sampel tembikar dari situs Cilellang adalah 62 fragmen, sedangkan dari situs Tobattang 44 fragmen.

\section{HASIL DAN PEMBAHASAN}

\section{Karakteristik Situs-situs Megalitik Wajo}

\section{Situs Tobattang}

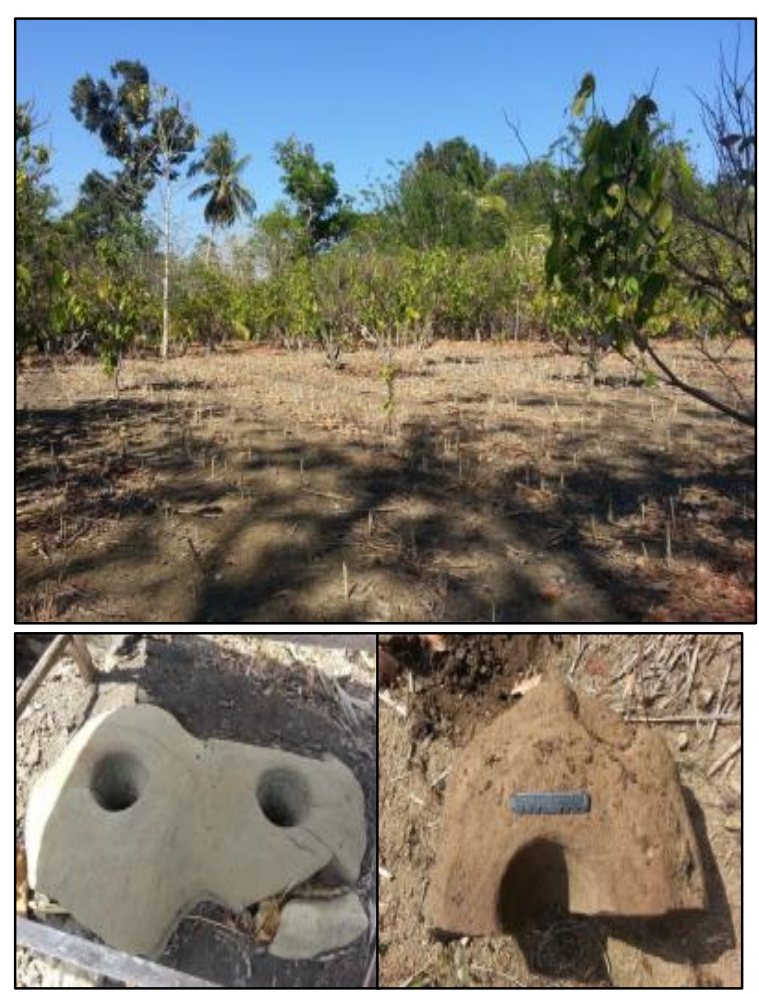

Gambar 1. Kondisi permukaan situs Tobattang dengan temuan lumpang batu yang memperlihatkan dua lubang dan lumpang yang sudah patah (Sumber: Balai Arkeologi Sulsel, 2014)

Situs Tobattang secara administratif berada di Desa Tobattang, Kecamatan Pammana, Kabupaten Wajo pada koordinat $4^{\circ}$ 14' 52,09" Lintang Selatan dan $120^{\circ} 3$ ' 3,01" Bujur Timur dengan ketinggian 61 meter di atas permukaan laut. Situs Tobattang pertama kali ditemukan berdasarkan informasi masyarakat setempat pada tahun 2014 ketika tim Balai 
Arkeologi Sulsel melakukan survei di wilayah Kecamatan Pammana. Lokasi situs berjarak sekitar $500 \mathrm{~m}$ dari pusat desa, dapat ditempuh dengan berjalan kaki melewati persawahan dan perkebunan

Areal situs merupakan perkebunan warga dengan tanaman pohon coklat, mangga, jambu mente, jagung dan sebagian tertutupi semak belukar. Permukaan tanah bergelombang lemah dengan luas $774,14 \mathrm{~m}^{2}$, memiliki sebaran temuan fragmen tembikar dan porselin cukup padat. Hingga kini belum dilakukan analisis terhadap temuan porselin tersebut. Selain temuan porselin dan tembikar, ditemukan pula delapan lumpang batu yang tersebar namun sebagian besar dalam kondisi rusak.

\section{Situs Allangkanange}

Situs Allangkanange terletak di Desa Wecudai, Kecamatan Pammana, Kabupaten Wajo pada koordinat $4^{\circ} 12^{\prime}$ 53,77' Lintang Selatan dan $120^{\circ} 2^{\prime} 49,00^{\prime}$ ' Bujur Timur dengan ketinggian 85 meter di atas permukaan laut. Situs Allangkanange telah diteliti pada tahun 1996 atas kerjasama Indonesia Australia dalam proyek Origin of Complex Society in South Sulawesi (OXIS). Penelitian tersebut bertujuan untuk meneliti basis sosial dan ekologis, munculnya kerajaan-kerajaan di wilayah penutur Bugis antara kisaran 1200 sampai 1600 Masehi (Bulbeck et al. 2008). Pada tahun 2015 tim dari Balai Arkeologi Sulawesi Selatan melakukan pemetaan ulang di lokasi tersebut untuk melengkapi data sebelumnya.

Lokasi situs berjarak $500 \mathrm{~m}$ dari jalan poros Kecamatan Pammana yang dapat ditempuh dengan kendaraan roda dua maupun empat melewati jalan pengerasan. Lokasi situs berada di sebuah puncak bukit dengan permukaan yang cukup datar. Hasil pemetaan menunjukkan bahwa luas sebaran tembikar di situs Allangkanange adalah $1796 \mathrm{~m},{ }^{2}$ dengan panjang maksimum luas sebaran adalah 564.88 m. Temuan fragmen tembikar lebih padat di bagian kaki bukit sebelah timur dibandingkan di bagian puncaknya. Selain itu, di situs ini ditemukan sebaran monumen megalitik (menhir, lumpang batu dan struktur temu gelang), fragmen tembikar dan porselin cukup merata di permukaan situs. Analisis temuan porselin selama ini menunjukkan kisaran waktu relatif antara abad ke-13 hingga abad ke-20 Masehi (Bulbeck et al. 2008).

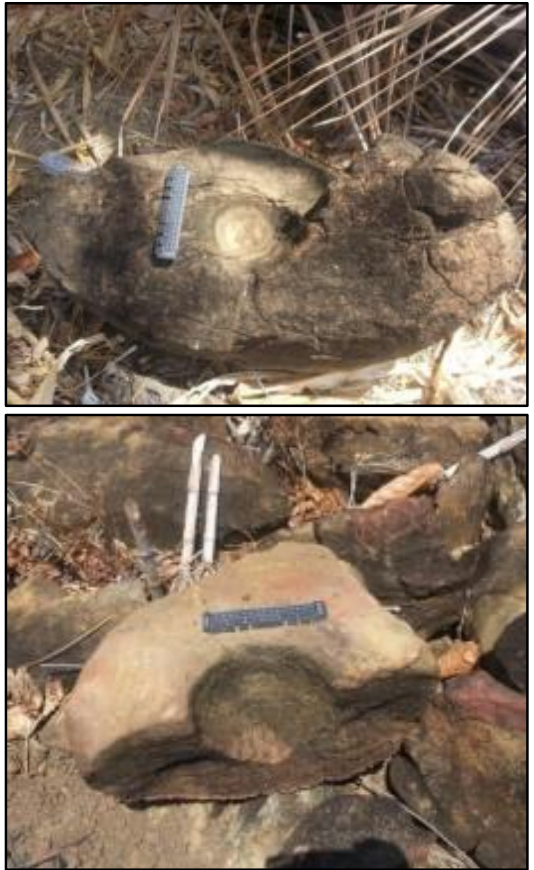

Gambar 2. Temuan lumpang batu yang masih utuh (atas) dan temuan lumpang yang patah (bawah)

(Sumber: Balai Arkeologi Sulsel, 2014)

Untuk tujuan identifikasi motif hias tembikar situs Allangkanange, maka dipilih 52 fragmen yang dijadikan sampel. Hasil identifikasi menunjukkan beberapa ragam motif hias tembikar, yaitu garis horizontal sejajar, garis vertikal sejajar, garis gelombang sejajar, garis diagonal sejajar, garis diagonal bersilangan sejajar, garis kotak silang dan titik. Adapun bentuk-bentuk motif hias yang dimaksud, dapat dilihat pada gambar 3 berikut:

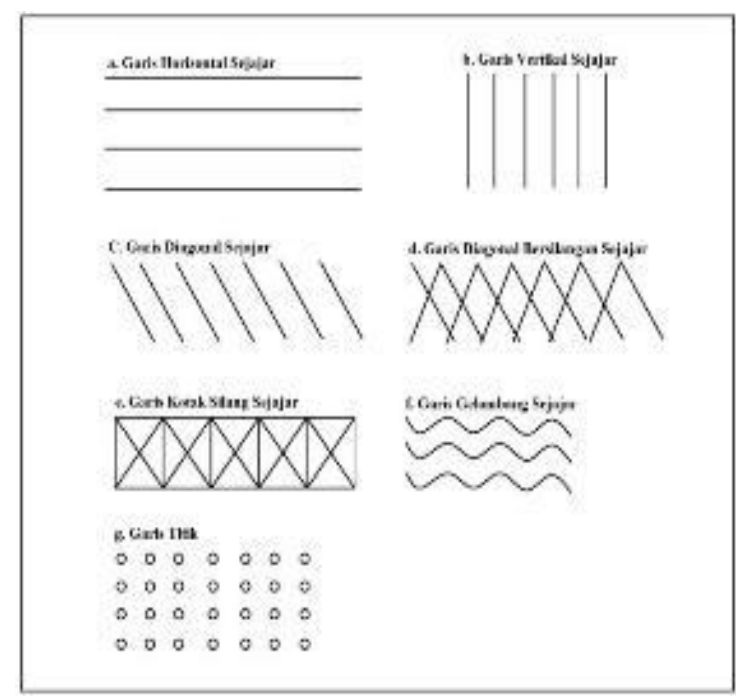

Gambar 3. Bentuk-bentuk motif hias tembikar situs Allangkanange

(Sumber: Hasil Penelitian Balar Sulsel, 2015) 


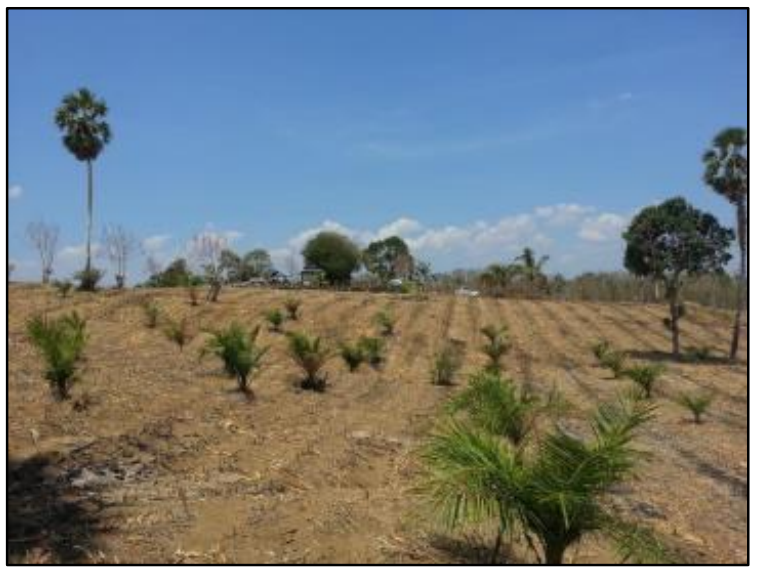

Gambar 4. Kondisi permukaan situs Allangkanange (Sumber: Balai Arkeologi Sulsel, 2015)

Secara keseluruhan, monumen megalitik jenis lumpang batu yang ditemukan di situs Allangkanange berjumlah 11. Sebagian besar lumpang batu ditemukan dalam kondisi yang sudah rusak. Kemungkinan kerusakannya karena adanya pengolahan kebun dan sawah oleh penduduk sekitar dengan cara membakar kebun sehingga lumpang batu tersebut banyak yang pecah. Sebagian lumpang batu ditemukan di sebelah timur di kaki bukit, sedangkan sebagian lainnya ditemukan di puncak bukit.

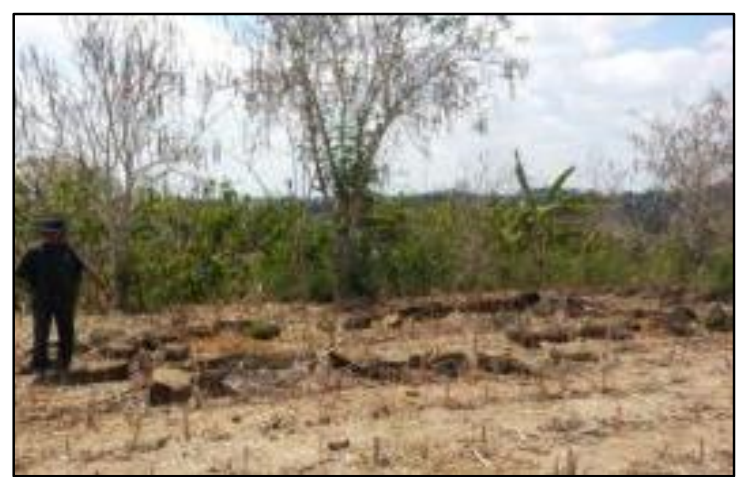

Gambar 5. Struktur batu temu gelang terletak di sudut barat laut situs Allangkanange

(Sumber: Balai Arkeologi Sulsel, 2015)

Temuan megalitik lain adalah empat struktur batu temu gelang yang ditemukan di lokasi yang berbeda. Secara keseluruhan, struktur batu temu gelang tersebut berada di sebelah barat situs di atas puncak bukit. Struktur batu temu gelang tersebut memperlihatkan ukuran yang berbeda-beda. Struktur batu temu gelang pertama memiliki bentuk persegi dengan ukuran panjang $40 \mathrm{~m}$. Bongkahan batu yang disusun berukuran rata- rata panjang $70 \mathrm{~cm}$. Pada bagian dalam struktur batu temu gelang pertama terdapat kompleks makam yang dianggap sebagai keturunan rajaraja Pammana. Beberapa makam memiliki arah hadap utara-selatan.

Struktur batu temu gelang kedua dan ketiga letaknya saling berdekatan berada di sudut barat laut situs. Struktur batu temu gelang kedua tersusun dengan bentuk persegi berukuran panjang lima meter, sedangkan struktur batu temu gelang ketiga berbentuk persegi panjang berukuran panjang dan lebar 4 $\mathrm{m} \times 1 \mathrm{~m}$. Struktur batu temu gelang keempat berada di sebelah timur struktur batu temu gelang kedua dan ketiga dengan susunan berbentuk persegi.

Selain itu, ditemukan sembilan menhir tersebar di dalam situs. Dua menhir di antaranya ditemukan di kaki bukit, sedangkan empat menhir lainnya ditemukan di puncak bukit. Tiga menhir ditemukan di dalam struktur batu temu gelang. Fungsi menhir-mehir tersebut belum diketahui secara pasti, namun menhir yang terdapat di dalam struktur temu gelang mungkin berfungsi sebagai tanda kuburan. Situs ini masih sering dikunjungi oleh masyarakat.

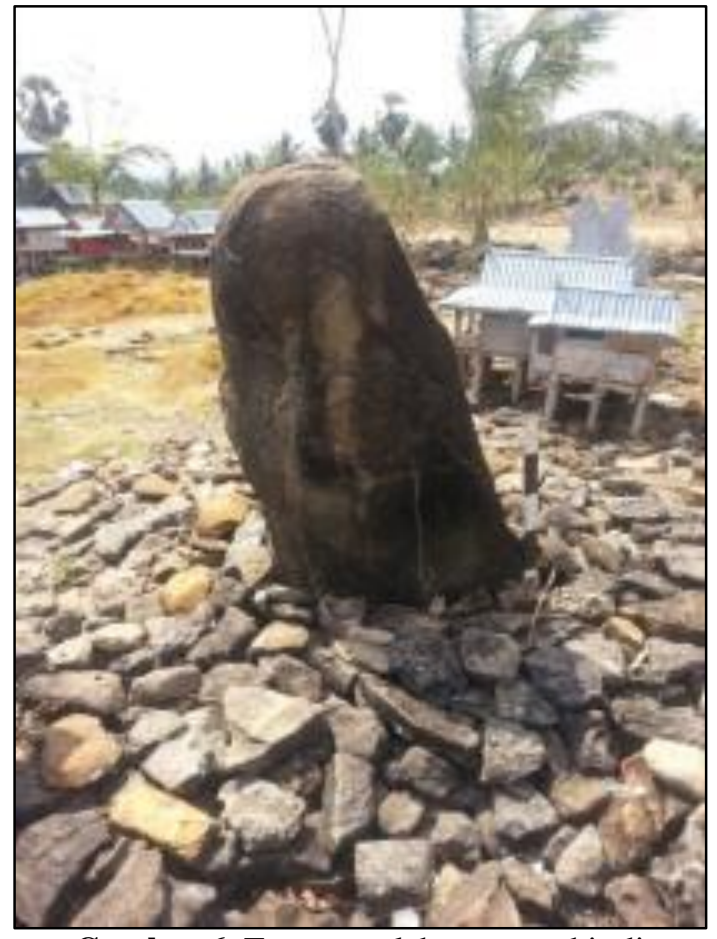

Gambar 6. Temuan salah satu menhir di dalam struktur batu Temu gelang pertama, situs Allangkanange

(Sumber: Balai Arkeologi Sulsel, 2015) 


\section{Situs Cilellang}
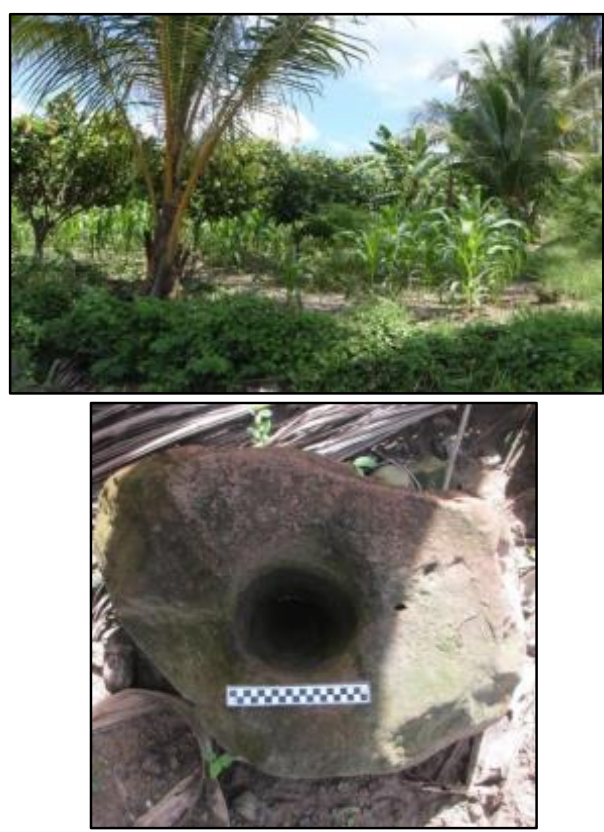

Gambar 7. Kondisi permukaan situs Cilellang dan salah satu lumpang batu yang memiliki satu lubang (Sumber: Balai Arkeologi Sulsel, 2014)
Situs Cilellang terletak di Desa Wecudai, Kecamatan Pammana, Kabupaten Wajo pada koordinat $04^{\circ} 14^{\prime}$ 02," Lintang Selatan dan $120^{\circ}$ 02' 57,6" Bujur Timur dengan ketinggian 58 meter di atas permukaan laut. Lokasi situs dapat ditempuh dengan berjalan kaki $100 \mathrm{~m}$ dari Kantor Desa Wecudai melewati perkebunan penduduk. Sepanjang jalan yang dilalui menuju ke situs, ditemukan fragmen tembikar dan porselin yang cukup padat dan tersebar dalam situs yang luasnya $\pm 1,1 \mathrm{~km}^{2}$. Data porselin yang dianalisis dari situs Cilellang merupakan temuan survei sebanyak 157 fragmen. Analisis keramik dibantu oleh Karaeng Demmanari (Purnabakti Balar Sulsel). Pertanggalan relatif dari hasil identifikasi keramik menunjukkan bahwa situs tersebut mungkin mulai muncul pada abad ke-13 $M$ dan perlahan mulai berkembang pada abad ke-14 $\mathrm{M}$ dengan puncak kejayaan pada abad ke-15, 16 dan $17 \mathrm{M}$. Namun perlahan mulai mengalami kemerosotan pada abad ke-18, 19 dan $20 \mathrm{M}$. Temuan lainnya yaitu 16 lumpang batu (sebagian besar berupa fragmen).

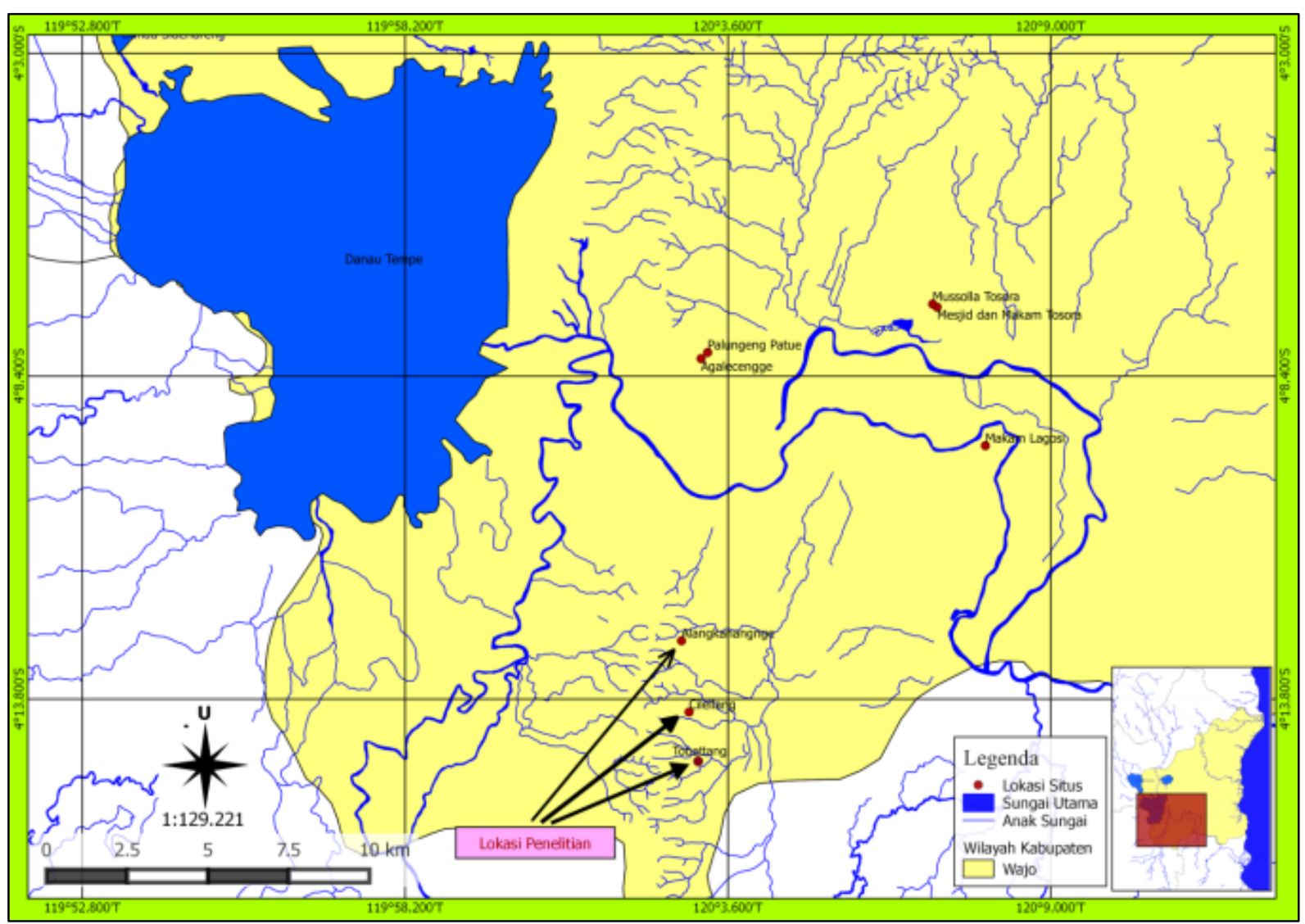

Gambar 8. Peta lokasi tiga situs megalitik yang terletak di sebelah tenggara Danau Tempe Kabupaten Wajo (Sumber: Balai Arkeologi Sulsel, 2015) 


\section{Lumpang Batu: Salah Satu Indikasi Permukiman Megalitik di Wajo}

Ketiga situs yang terletak di sebelah tenggara Danau Tempe (Gambar 8) merupakan situs permukiman dengan indikasi temuan megalitik berasosiasi dengan tembikar dan porselin. Di antara ketiga situs tersebut, situs Allangkanange merupakan situs yang pernah diteliti pada tahun 1996 oleh Bulbeck dan Caldwell dalam proyek Origin of Complex Society in South Sulawesi (OXIS). Hasil penelitian menunjukkan bahwa situs Allakanange diokupasi sejak abad ke-13 M yaitu sebelum para elit kerajaan di Sulawesi Selatan memeluk agama Islam (Bulbeck, et al., 2008).

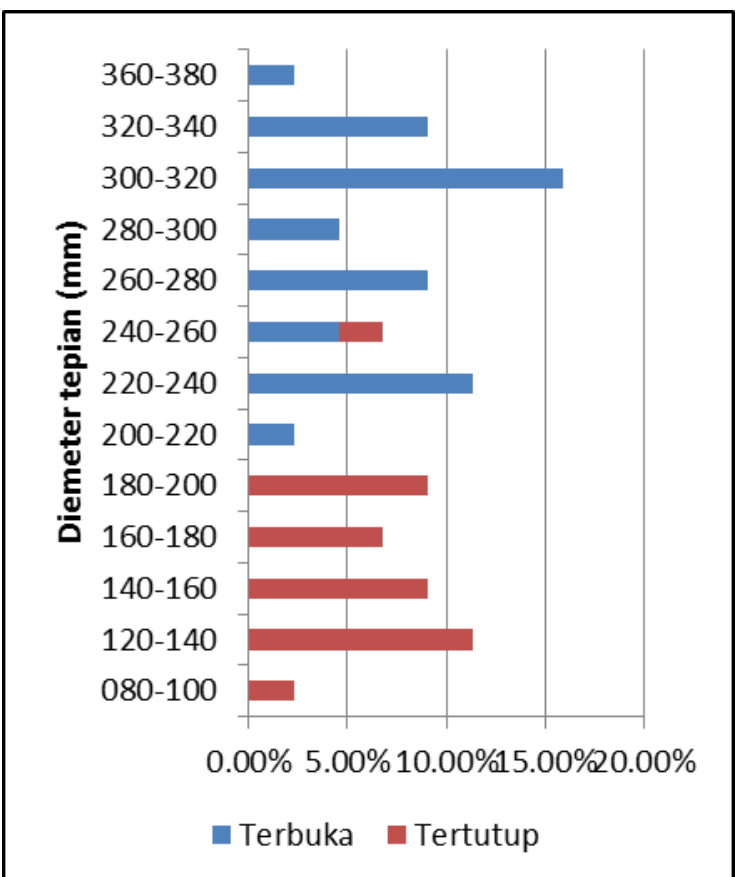

Gambar 9. Frekuensi temuan wadah tembikar situs Cilellang

(Sumber: Balai Arkeologi Sulsel, 2015)

Lumpang batu merupakan jenis budaya material yang umum dijumpai pada sejumlah situs megalitik di Sulawesi Selatan (Hasanuddin, et al., 2015: 358). Melihat ukuran kedalaman lubang menunjukkan bahwa lumpang-lumpang batu tersebut memiliki fungsi yang sama yaitu untuk menumbuk bijibijian. Temuan lumpang batu berjumlah 36 pada ketiga situs menunjukkan bentuk lubang mengerucut dengan permukaan lubang yang halus. Hal ini mengindikasikan tingginya intensitas penggunaannya dalam mengolah bahan makanan dalam kehidupan sehari-hari. Data statistik menunjukkan bahwa diemeter lubang lumpang batu pada situs Allangkanange adalah rata-rata $20,27 \mathrm{~cm}$, situs Cilellang ratarata $20,94 \mathrm{~cm}$, dan situs Tobattang rata-rata $20,13 \mathrm{~cm}$. Dengan demikian, ukuran diemeter lubang lumpang batu pada ketiga situs tidak memperlihatkan perbedaan yang signifikan.

Tampaknya mereka mempunyai gagasan yang sama (mental template) dalam membuat lumpang batu. Bahan yang mereka gunakan adalah batu andesit yang materialnya cukup tersedia di lingkungan situs.

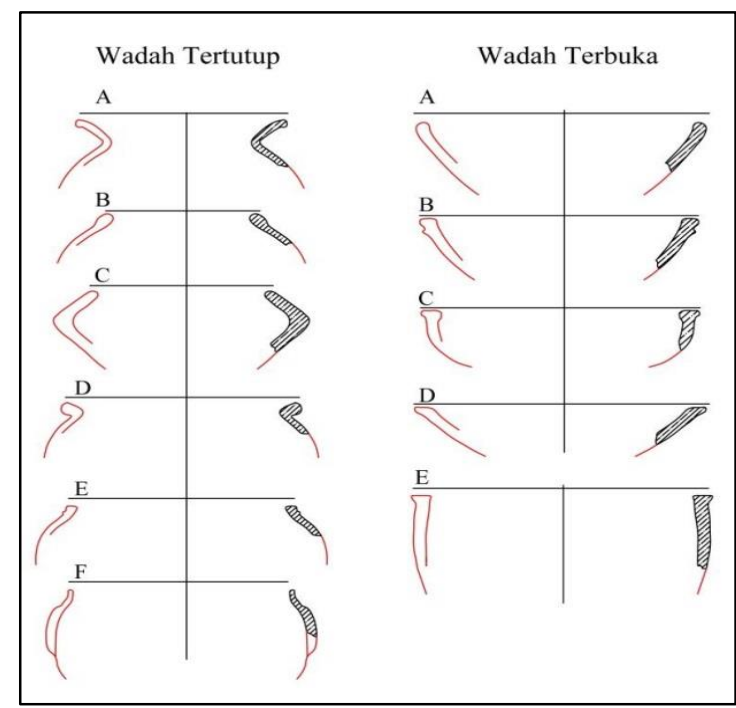

Gambar 10. Varian-varian bentuk wadah terbuka dan tertutup dari analisis tepian tembikar (Sumber: Balai Arkeologi Sulsel, 2015)

Lumpang batu di situs-situs permukiman senantiasa dihubungkan dengan aktivitas pengolahan bahan makanan. Fungsi lumpang batu sebagai wadah perlengkapan kehidupan sehari-hari yang erat kaitannya dengan pertanian (Sukendar, 1985: 53-54). Hasil studi etnografi yang telah dilakukan oleh beberapa peneliti di daerah lain, menemukan adanya keterkaitan antara lumpang batu dengan sistem permukiman, dimana setiap rumah memiliki lumpang batu yang digunakan sebagai wadah untuk menumbuk biji-bijian (seperti padi, jagung dan jenis biji-bijian yang lain). Soejono (1984: 217) memberikan asumsi tentang hasil penelitiannya di Sumatera Selatan, bahwa lumpang batu digunakan sebagai wadah untuk menumbuk padi.

Selain lumpang batu, temuan yang paling menonjol adalah fragmen tembikar yang 


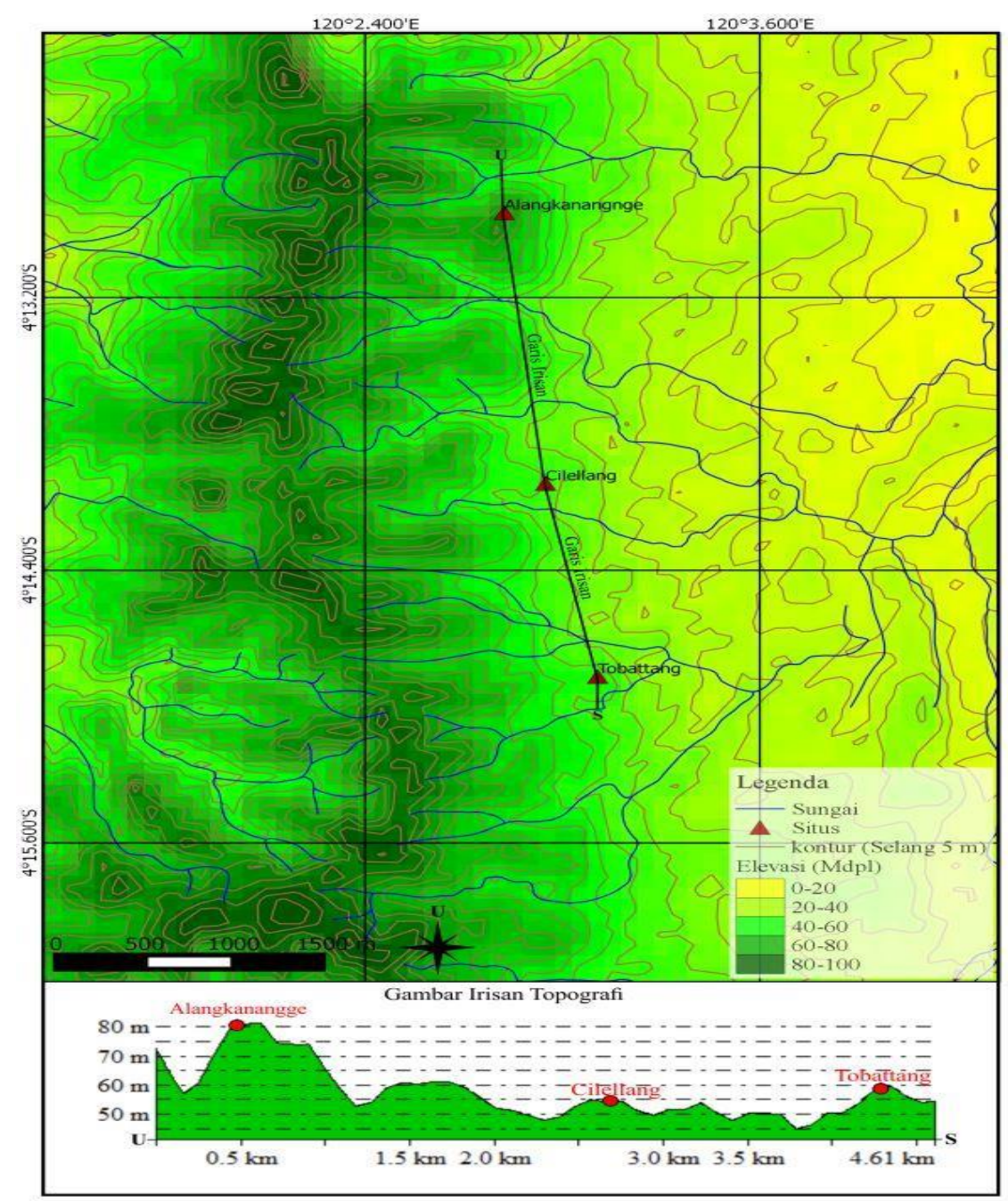

Gambar 11. Kondisi Topografi letak situs Allangkanange, Cilellang dan Tobattang (Sumber: Balai Arkeologi Sulsel, 2015)

persebarannya cukup padat pada ketiga situs. Data analisis diameter lingkaran tepian (interval $20 \mathrm{~mm}$ ) pada situs Cilellang dan Tobattang menunjukkan bahwa diameter tepian tembikar 300-320 mm dan 320-340 mm untuk wadah tertutup paling dominan ditemukan di situs Cilellang. Hal tersebut tidak berbeda dengan situs Tobattang, dimana wadah tertutup dengan diemeter 300-320 $\mathrm{mm}$ dan 320-340 $\mathrm{mm}$ juga dominan ditemukan. Wadah tembikar tertutup dengan diameter 300-320 mm dan 320-340 mm biasanya merupakan wadah periuk. Tampaknya wadah periuk adalah wadah yang paling dominan ditemukan pada kedua situs ini.

Wadah terbuka dengan diameter 120-140 $\mathrm{mm}, \quad 140-160 \mathrm{~mm}$ dan 220-240 $\mathrm{mm}$ adalah wadah paling dominan ditemukan di situs Cilellang. Hal tersebut tidak berbeda signifikan dengan temuan dari situs Tobattang. Wadah terbuka yang juga dominan adalah 120-140 $\mathrm{mm}, 140-160 \mathrm{~mm}$ dan 180-200 mm. Mungkin wadah terbuka yang memiliki diameter 120-140 $\mathrm{mm}$ adalah wadah mangkuk. Di situs Cilellang, wadah terbuka dengan diameter 220-240 mm cukup banyak ditemukan. Mungkin wadah piring atau jambangan banyak ditemukan di situs Cilellang dibandingkan di situs Tobattang. Varian-varian wadah tembikar dari analisis tepian dapat dilihat pada gambar 10 .

\section{Masa Hunian dalam Konteks Temuan Megalitik Wajo}

Berdasarkan data sebaran tembikar menunjukkan bahwa situs Allangkanange mempunyai areal situs yang lebih luas dibandingkan situs Cilellang dan Tobattang. Situs Allangkanangge mempunyai luas 1,79 $\mathrm{km}^{2}$, situs Tobattang adalah situs yang mempunyai areal paling kecil dengan luas hanya $263 \mathrm{~m}^{2}$, sedangkan situs Cilellang mempunyai luas areal $1,04 \mathrm{~km}^{2}$. Selain situs Allangkanange mempunyai areal yang cukup luas, situs ini juga berada pada daerah permukaan yang cukup tinggi dibandingkan 
situs Cilellang dan situs Tobattang. Situs Allangkanange berada pada ketinggian 85 meter di atas permukaan laut, sedangkan situs Tobattang hanya berada pada ketinggian 61 meter di atas permukaan laut dan situs Cilellang terletak pada ketinggian 54 meter di atas permukaan laut. Temuan di situs Allangkanange juga lebih bervariasi dibandingkan dengan situs Cilellang dan Tobattang.

Penjelasan data luas areal situs, ketinggian dari permukaan laut dan variasi tinggalan arkeologi menunjukkan korelasi yang cukup kuat dari ketiga variabel tersebut. Artinya situs Allangkanange yang letaknya lebih tinggi dibanding kedua situs yang lainnya dan memiliki tingkat variabilitas temuan arkeologi yang tinggi. Hasil perbandingan ketiga situs megalitik di Wajo menunjukkan bahwa situs Allakanange mempunyai ukuran situs terluas dengan jenis temuan megalitik yang lebih bervariasi dibandingkan dengan situs Cilellang dan Tobattang. Dengan demikian, berkembang pada masa ke-14 $\mathrm{M}$ dengan puncak kejayaannya pada masa abad ke-15, 16 dan 17 M. Namun secara perlahan mengalami kemunduran pada abad ke-18, 19 dan $20 \mathrm{M}$. Kemerosotan permukiman di situs-situs tersebut diakibatkan oleh krisis politik pada abad ke-17 M dan mengharuskan ditinggalkannya situs-situs tersebut di paruh kedua abad itu (Bulbeck et al. 2009).

Ekskavasi di situs Cilellang dengan membuka kotak berukuran $2 \mathrm{~m}$ x $1 \mathrm{~m}$ dilakukan di sisi barat salah satu lumpang batu. Data analisis radiokarbon dari temuan arang hasil ekskavasi tersebut menunjukkan bahwa permukiman di Cilellang berlangsung pada abad ke-13 M hingga abad ke-15 M (lihat tabel 1). Hal ini menunjukkan bahwa terdapat kesesuaian analisis porselin oleh Bulbeck di situs Allangkanange dengan analisis radiokarbon dari situs Cilellang. Kesesuaian itu menunjukkan bahwa masa okupasi situs-situs megalitik yang diteliti memiliki rentang masa antara abad ke-13 hingga abad ke-15 M.

Tabel 1. Hasil Analisis Radiokarbon Situs Cilellang, Wajo, Sulawesi Selatan

\begin{tabular}{cccccc}
\hline No. Sampel & Kedalaman $(\mathrm{cm})$ & Asosisasi & Kronologi & Cal. CE & Abad \\
\hline CLL/TP1/SB/4/13 & $z=60$ & Lumpang batu, tembikar & $605 \pm 30$ BP & $1296-1406$ & $13-15 \mathrm{Masehi}$ \\
\hline CLL/TP1/SB/8/13 & $\mathrm{z}=100$ & Lumpang batu, tembikar & $735 \pm 40 \mathrm{BP}$ & $1215-1384$ & $13-14 \mathrm{Masehi}$ \\
\hline
\end{tabular}

Sumber: Analisis C14 oleh Pusat Aplikasi Isotop dan Radiasi, Batan, Jakarta. Kalibrasi dibantu oleh David

Bulbeck menggunakan perhitungan Oxcal 4.2.

mungkin situs Allangkanange merupakan situs permukiman dengan berbagai aktivitas, seperti hunian, religi dan aktivitas sosial (gotong royong dan kepemimpinan).

Ketiga situs merupakan situs permukiman dengan indikasi temuan lumpang batu, tembikar dan porselin. Analisis keramik asing oleh Bulbeck di situs Allangkanange menunjukkan bahwa situs tersebut mulai muncul pada abad ke-13 $\mathrm{M}$ dan perlahan
Gambar 12 adalah stratigrafi situs Cilellang yang memperlihatkan empat lapisan tanah. Lapisan pertama merupakan tanah humus bertekstur lanau yang agak padat dengan warna coklat gelap. Lapisan ini terlihat hingga kedalaman permukaan spit 2 di dinding selatan dan barat. Lapisan kedua merupakan batuan pasir yang lapuk dengan warna abu-abu. Lapisan ini terlihat pada dinding timur, sebagian dinding utara dan selatan dan mulai

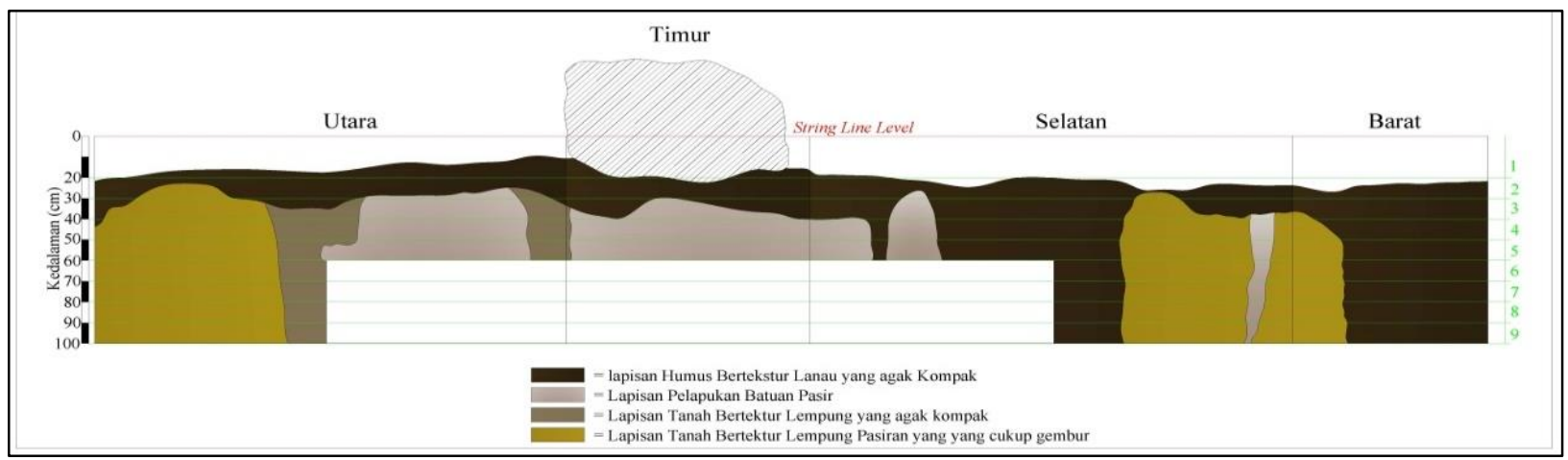

Gambar 12. Stratigrafi ekskavasi situs Cilellang

(Sumber: Balai Arkeologi Makassar, 2014) 
terlihat pada kedalaman $25 \mathrm{~cm}$. Lapisan ketiga merupakan tanah bertekstur lempung yang agak kompak dengan warna coklat kekuningan. Lapisan ini mulai terlihat pada kedalaman 25 $\mathrm{cm}$ di dinding utara. Lapisan keempat merupakan tanah bertekstur lempung berpasir yang cukup gembur. Lapisan ini mulai terlihat pada kedalaman $23 \mathrm{~cm}$ di dinding utara, selatan dan barat.

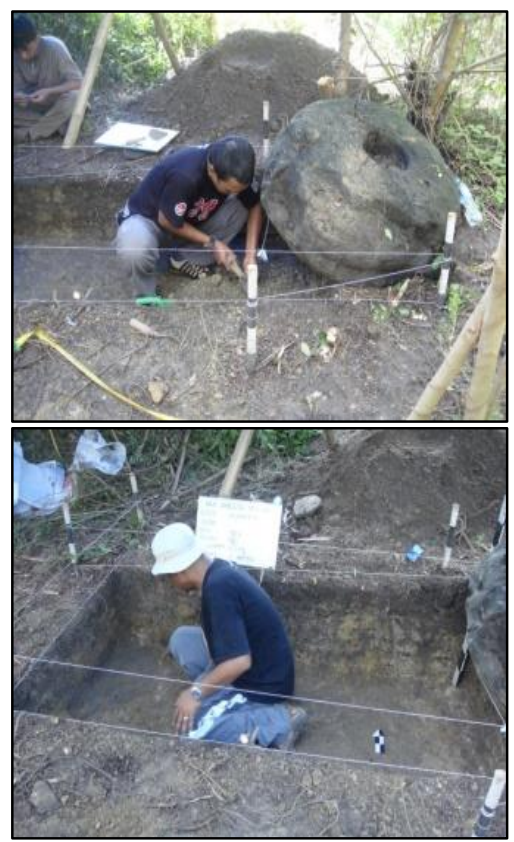

Gambar 13. Kotak ekskavasi dengan asosiasi lumpang batu di situs Cilellang, Wajo

(Sumber: Hasil Penelitian, 2014)

Pada sudut barat daya ditemukan fitur dari kedalaman $25-100 \mathrm{~cm}$. Fitur tersebut mungkin bekas galian yang memiliki tekstur tanah gembur berwarna hitam keabu-abuan. Asosiasi temuan dalam fitur adalah fragmen tembikar dan arang. Arang yang ditemukan dalam fitur selanjutnya dianalisis untuk memperoleh pertanggalan. Hal ini mengingat bahwa temuan tersebut memiliki hubungan secara kontekstual dengan lumpang batu.

Tabel 2 memperlihatkan jenis temuan yang terdiri dari fragmen tulang, artefak batu, fragmen tembikar, fragmen porselin, dan uang logam. Fragmen tulang, porselin dan uang logam hanya ditemukan pada spit 1 , sedangkan artefak batu ditemukan pada spit 1 dan 2 . Fragmen tembikar pada spit 1 berjumlah 293 fragmen. Namun, mengalami penurunan yang sangat drastis pada spit 2 dengan jumlah 18 fragmen hingga spit 8 dengan jumlah 12 fragmen. Temuan tembikar pada spit 3 hingga spit spit 8 hanya terkonsentrasi pada lapisan fitur. Artefak batu yang ditemukan pada spit 1 dan 2 adalah serpih yang memperlihatkan persamaan teknologi dengan serpih di Cabbenge (Soppeng) dimana kedua wilayah tersebut (Wajo dan Cabbenge) letaknya berdekatan. Temuan empat serpih di Cilellang mungkin merupakan pengendapan dari aliran Sungai Walennae yang mengalir di sebelah timur situs Cilellang. Lapisan tanah tempat ditemukannya serpih tersebut merupakan tanah hasil pengendapan sungai dengan struktur lapukan batu pasir dengan warna tanah abu-abu.

Penempatan permukiman di wilayah ini sangat didukung oleh ketersediaan sumber alam yang ditunjang oleh tanah yang subur. Hal itu masih terlihat sekarang yaitu di sekitar situs terdapat hamparan persawahan dan perkebunan. Selain itu, situs ini memiliki kandungan tanah lempung dan pasir yang sangat sesuai untuk pembuatan wadah tembikar yang banyak dibutuhkan untuk menunjang kehidupan manusia. Hasil wawancara kami dengan masyarakat di sekitar situs diperoleh penjelasan

Tabel 2. Jenis dan jumlah temuan di kotak ekskavasi situs Cilellang, Wajo

\begin{tabular}{|c|c|c|c|c|c|c|}
\hline \multirow[b]{2}{*}{ Spit } & \multicolumn{5}{|c|}{ Temuan } & \multirow[b]{2}{*}{ Jmlh } \\
\hline & Artefak Batu & $\begin{array}{l}\text { Fragmen } \\
\text { Porselin }\end{array}$ & $\begin{array}{l}\text { Fragmen } \\
\text { Tembikar }\end{array}$ & $\begin{array}{l}\text { Fragmen } \\
\text { Tulang }\end{array}$ & Uang Logam & \\
\hline 1 & 3 & 4 & 293 & 4 & 2 & 306 \\
\hline 2 & 1 & & 18 & & & 19 \\
\hline 3 & & & 3 & & & 3 \\
\hline 4 & & & 5 & & & 5 \\
\hline 5 & & & 5 & & & 5 \\
\hline 6 & & & 7 & & & 7 \\
\hline 7 & & & 6 & & & 6 \\
\hline 8 & & & 12 & & & 12 \\
\hline Jml & 4 & 4 & 349 & 4 & 2 & 363 \\
\hline
\end{tabular}

Sumber: Hasil Penelitian Balar Sulsel, 2014 
bahwa masyarakat masih memperoduksi wadah tembikar hingga tahun 1960an yang sumber tanahnya diperoleh di Cilellang dan sekitarnya.

\section{KESIMPULAN}

Situs-situs megalitik di Wajo terletak di sebelah tenggara Danau Tempe. Ketiga situs yang telah diteliti memiliki variabilitas temuan berupa peninggalan megalitik, fragmen tembikar dan porselin. Dari aspek temuan megalitik, situs Allakanange, Cilellang, dan Tobattang memiliki variabilitas temuan yang sama, dalam pengertian bahwa ketiga-tiganya memiliki temuan megalitik yang berasosiasi dengan tembikar dan porselin. Namun dari segi jenis temuan megalitik, situs Allangkanange memiliki jenis temuan yang lebih bervariasi. Pada situs Allakanange ditemukan menhir, susunan batu temu gelang dan lumpang batu. Pada situs Cilellang dan Tobattang hanya ditemukan peninggalan megalitik berupa lumpang batu. Berdasarkan jenis temuan megalitik dan luas masing-masing situs tersebut, disimpulkan bahwa situs Allangkanange mungkin mempunyai strata sosial permukiman yang tinggi dibandingkan kedua situs lainnya, karena memiliki luas situs paling besar dengan tingkat variabilitas temuan yang tinggi. Dari kondisi topografi juga menunjukkan bahwa situs Allakanange memiliki areal yang lebih tinggi dibandingkan dengan kedua situs yang lainnya.

Sesuai pertanggalan yang dihasilkan di situs Cilellang menunjukkan masa okupasi situs-situs megalitik di Wajo berlangsung antara abad ke-13-15 Masehi. Hasil ini membuktikan bahwa di wilayah ini peradaban manusia dimulai lebih awal dibandingkan dengan masa yang diungkapkan dalam naskah lontara yang hanya merujuk pada abad ke-15 Masehi. Ketika itu permukiman manusia terletak di atas puncak bukit yang mungkin dimaksudkan untuk keamanan dan menghindar dari banjir yang sewaktu-waktu dapat terjadi. Ketiga situs terletak di sekitar aliran Sungai Walennae yang berpotensi untuk banjir ketika air sungai meluap. Hal itu terlihat dari kandungan tanah jenis pasir halus dan lanau. Data geologi juga menunjukkan bahwa kawasan ketiga situs tersebut merupakan Formasi Walannae yang terdiri dari batu pasir, batu lanau, tufa, napal, batu lempung, konglomerat dan batu gamping. Hal ini menunjukkan bahwa situs
Allangkanange, Cilellang, dan Tobattang masih merupakan endapan Sungai Walannae.

\section{Ucapan Terima Kasih}

Terima kasih kepada Pak Wahyu dan Ibu Retno Handini (Pusat Penelitian Arkeologi Nasional) yang telah memediasi untuk pertanggalan Radiokarbon di Pusat Aplikasi Isotop dan Radiasi, Batan Jakarta. Terima kasih pula disampaikan kepada seluruh anggota tim yang telah membantu dalam proses penelitian di Wajo.

\section{$* * * * *$}

\section{DAFTAR PUSTAKA}

Abidin, Z. (1985). Wajo abad XV - XVI Suatu Penggalian Sejarah Terpendam Sulawesi Selatan dari Lontara. Bandung: Alumni.

Balar Sulsel. (2014). Laporan Penelitian Situs Cilellang, Kabupaten Wajo. Tidak terbit.

Balar Sulsel. (2015). Situs-situs di Sebelah Tenggara Danau Tempe, Kabupaten Wajo. Tidak terbit.

Bulbeck, D., \& Caldwell, I. (2000). The Land of Iron: The Historical Archaeology of Luwu and The Cenrana Valley. Hull: University of Hull, Centre for South-East Asian Studies.

Bulbeck, D. \& I. Caldwell. (2008). Oryza Sativa and The Origins Of Kingdoms In South Sulawesi, Indonesia: Evidence from Rice Husk Phytoliths. Indonesia and the Malay World, 36(104), 1-20. London: Routledge.

Bulbeck, D., \& Hakim, B. (2009). The Earthenware form Allangkanangnge ri Latanete Excavated in 1999. Walennae, 11(2), 99-106.

Caldwell, I. (1995). Power, State and Society Among The Pre-Islamic Bugis. Bijdragen tot de Taal-, Land-en Volkenkunde, 151(3), 394421.

Duli, Akin. (1988). Peninggalan Arkeologi di Tosora. Skripsi Arkeologi Universitas Hasanuddin.

Duli, Akin. (2010). Peranan Tosora sebagai Pusat Pemerintahan Kerajaan Wajo Abad XVI XIX. Walennae, 12(2), 143-158.

Hadimulyono. (1985). Studi Kelayakan Bekas Ibu Kota Kerajaan Wajo (Abad XVII) di Tosora, Kabupaten Wajo Sulawesi Selatan. Ujung Pandang: SPSP Sulselra. Tidak terbit.

Hamris. (1990). Bentuk Nisan Kompleks Makam Raja-Raja Wajo di Tosora. Skripsi Arkeologi Universitas Hasanuddin.

Hasanuddin, \& Chia, S. (2015). Megalitik dan Hubungannya dengan Sistem Pertanian di 
Sulawesi Selatan. Dalam Prasetyo, B., \& N. Rangkuti, (Ed.), Pernak-Pernik Megalitik Nusantara (pp. 345-376). Yogyakarta: Galangpress.

Kallupa, Bahru. (1987). Laporan Ekskavasi Penyelamatan di Desa Tosora Kecamatan Majauleng Kabupaten Wajo. Ujung Pandang: SPSP Sulselra. Tidak terbit.

Nurhikmah. (1995). Kepemimpinan La Tadampare Puang Ri Maggalatung sebagai Arung Matowa Wajo IV (1491-1521): Suatu Tinjauan Historis. Skripsi Jurusan Sejarah Universitas Hasanuddin.

Patunru, A. R. D. (1983). Sejarah Wajo. Ujung Pandang: Yayasan Kebudayaan Sulselra.

Soejono, R. P., (Ed.). (1984). Sejarah Nasional Indonesia I. Jakarta: Balai Pustaka.

Sukendar, Haris. (1985). Peranan Menhir dalam Masyarakat Prasejarah di Indonesia. Prosiding Pertemuan Ilmiah Arkeologi III (pp. 92-106). Ciloto: Ikatan Ahli Arkeologi Indonesia. 